\title{
Keragaman M1 tanaman hias bunga matahari (Helianthus annuus 1.) akibat iradiasi sinar gamma
}

\author{
(Variability of M1 sunflower ornamental plant affected by gamma ray irradiation) \\ I. N. S. Monikasari, S. Anwar, B. A. Kristantanto \\ Agroecotechnology, Faculty of Animal and Agricultural Sciences, Diponegoro University \\ Tembalang Campus, Semarang 50275 - Indonesia \\ Corresponding E-mail: intannovelasm@gmail.com
}

\begin{abstract}
The purpose of the research was to obtain the morphological variability of M1 sunflower ornamental plant and information of lethal doses $\left(\mathrm{LD}_{50}\right)$ effect of mutation by gamma ray irradiation. The research was arranged in monofactor experimental with Completely Randomized Design (CRD) with 5 treatments and 5 replications, each replication consisted of 5 sunflower seeds was irradiated by gamma ray of $0,5,25,45$, and $65 \mathrm{~Gy}$. The data observed were analyzed by anova and followed with BNT of 5\% level. Parameters observed included germination, plant height, stem diameter, tube flower diameter, tribbon flower diameter, initiation time, perfect bloom age, chlorophyll, ribbon flower number, seed number, total seed weight, weight of 100 seeds, LD $_{50}$, Flower color and heritability. The result showed that irradiation significantly affected to plant height, stem diameter, tube flower diameter, ribbon flower diameter, initiation time, seeds number, seed weight, weight of 100 seeds. Lethal doses of sunflower was 74,19 Gy. Heritability values ranged from 23.47 to $73.81 \%$.
\end{abstract}

Keywords : Helianthus annus $L .$, irradiation, $L D_{50}$, heritability

\begin{abstract}
ABSTRAK
Penelitian ini bertujuan untuk memperoleh keragaman morfologi M1 tanaman hias bunga matahari (Helianthus annuus $\mathrm{L}$.) dan nilai $\mathrm{LD}_{50}$ akibat iradiasi sinar gamma. Penelitian menggunakan percobaan monofaktor dengan rancangan acak lengkap (RAL) terdiri dari 5 perlakuan iradiasi sinar gamma dengan 5 ulangan, setiap ulangan terdiri dari 5 benih bunga matahari dengan dosis penyinaran $0,5,25$, 45, dan 65 Gy. Data hasil pengamatan diolah secara statistik analisis ragam (anova) dengan uji lanjut BNT taraf $5 \%$. Parameter yang diamati meliputi umur berkecambah, tinggi tanaman, diameter batang, diameter bunga tabung, diameter bunga pita, umur inisiasi bunga, umur mekar sempurna, klorofil, jumlah bunga pita, jumlah biji, berat biji, bobot 100 biji, LD $_{50}$, warna bunga dan heritabilitas. Hasil penelitian menunjukkan bahwa iradiasi sinar gamma memberikan pengaruh nyata terhadap tinggi tanaman, diameter batang, diameter bunga tabung dan pita, umur inisiasi bunga, jumlah biji, berat biji, bobot 100 biji. Nilai $\mathrm{LD}_{50}$ bunga matahari adalah 74,19 Gy. Nilai heritabilitas berkisar antara 23,47-73,81\%.

Kata kunci: Helianthus annuus L., Iradiasi gamma, $\mathrm{LD}_{50}$, heritabilitas
\end{abstract}

\section{PENDAHULUAN}

Bunga matahari (Helianthus annuus L.) merupakan tanaman hias introduksi yang berasal dari Amerika Utara. Bunga matahari mampu beradaptasi pada daerah yang panas dengan pencahayaan yang penuh, akan tetapi pertumbuhannya tidak dipengaruhi oleh fotoperiodisme. Penikmat tanaman hias lebih menyukai tanaman hias yang memiliki keragaman atau keunikan tersendiri. Peningkatan keragaman tersebut bisa dibantu dengan adanya pemuliaan tanaman. Pemuliaan tanaman adalah ilmu tentang penyeleksian dan keragaman terhadap bentukbentuk tanaman yang ingin dikembangkan (Syukur et al., 2012). 
Salah satu teknik pemuliaan tanaman yang digunakan untuk meningkatkan keragaman tanaman adalah melalui mutasi. Mutasi mampu menimbulkan keragaman genetik dalam pemuliaan tanaman. Penyinaran iradiasi sinar gamma termasuk mutasi fisik yang hasilnya lebih baik dibanding mutasi kimia karena daya serap yang rendah pada bagian vegetatif tanaman terhadap bahan mutasi. Mutasi fisik menyebabkan terjadinya perubahan pada tingkat genom, kromosom, dan DNA sehingga proses fisiologi pada tanaman menjadi tidak normal dan menghasilkan variasi genetik baru (Balitan, 2011). Efek dari penyinaran tersebut mengakibatkan tanaman yang diberi perlakuan iradiasi akan berbeda dengan indukannya atau terbentuknya jenis baru (Suwarno et al., 2013). Metwally et al. (2015) berpendapat bahwa efek dari radiasi menyebabkan perubahan dalam struktur seluler tanaman dan metabolisme tanaman seperti pelebaran membran tilakoid dan perubahan dalam fotosintesis.

Penelitian mutasi fisik pada benih matahari sebelumnya menggunakan dosis penyinaran sebesar 0, 20, 40, dan 60 gray (Saputra, 2012). Dosis iradiasi sinar gamma yang tinggi (100-400 Gy) menyebabkan kematian pada tanaman karena iradiasi mampu merusak DNA (Nura, 2015). Efek negatif pemberian iradiasi sinar gamma adalah adanya pembelahan sel dan pertumbuhan pertanaman yang terhambat (Maharani dan Khumaida, 2013). Menurut Suwarno et al. (2013) iradiasi gamma juga dapat memacu pertumbuhan akar semakin cepat.

Penelitian ini bertujuan untuk memperoleh keragaman morfologi M1 tanaman hias bunga matahari (Helianthus annuus L.) dan nilai LD50 akibat penyinaran iradiasi sinar gamma.

\section{MATERI DAN METODE}

\section{Materi}

Penelitian telah dilaksanakan pada bulan Februari 2017-Mei 2017 di Kecamatan Kebakramat, Kabupaten Karanganyar. Perlakuan iradiasi sinar gamma dilakukan di Laboratorium Pusat Penelitian dan Pengembangan Teknologi Isotop dan Radiasi, Badan Tenaga Atom Indonesia (Batan), Pasar Jumat, Jakarta. Materi yang digunakan antara lain benih matahari jenis Giant Single (Mr. Fothergills, UK) hasil induksi mutasi melalui radiasi sinar gamma $(0,5,25,45$, dan 65 Gy), tanah, arang sekam, pupuk NPK, gandasil b, gandasil d, pupuk kandang, pestisida, dan insektisida. Peralatan yang digunakan dalam penelitian ini antara lain iradiator gamma chamber 4000A, tray, polibag sebanyak 125 buah dengan ukuran $40 \times 40 \mathrm{~cm}$, alat siram, cangkul, cetok, meteran, label, gunting, amplop, plastik, dan alat tulis.

\section{Metode}

Penelitian ini disusun menggunakan percobaan monofaktor dengan rancangan acak lengkap (RAL) terdiri dari 5 perlakuan iradiasi sinar gamma dan 5 ulangan, setiap ulangan terdiri 5 benih bunga matahari. Perlakuan iradiasi sinar gamma yang dicobakan adalah dosis $0,5,25,45$, dan 65 Gy.

Penelitian dilaksanakan melalui beberapa tahap meliputi persiapan benih bunga matahari dan perlakuan iradiasi, persemaian benih dalam tray, transplanting ke polibag dan pemeliharaan. Transplanting dilakukan ketika bibit sudah memiliki 2 helai daun (12 hari setelah semai/ HSS) di polibag ukuran $40 \times 40 \mathrm{~cm}$ yang telah berisi tanah, pupuk kandang, dan sekam $(2: 1: 1)$, kemudian diberi pupuk dasar NPK (15:15:15) dengan dosis $2 \mathrm{~g} /$ polibag (Khotimah, 2007). Pemupukan dilakukan setiap satu minggu sekali dengan pupuk gandasil $\mathrm{b}$ dan gandasil $\mathrm{d}$ dengan dosis 2g/ liter tiap tanaman (Saputra, 2012).

Pengamatan. Karakter yang diamati adalah karakter kuantitatif dan kualitatif. Pengamatan karakter kuantitatif meliputi (1) Umur berkecambah benih (hari), (2) Tinggi tanaman (cm), (3) Diameter batang bunga (cm), (4) Umur inisiasi bunga (Hari Setelah Transplanting/ HST), yaitu umur tanaman pada waktu munculnya pembungaan pertama, (5) Umur mekar sempurna dihitung sejak hss (hari), (6) Diameter bunga pita dan bunga tabung (cm),(8) Total berat biji (g), (9) Total jumlah biji. (10). Bobot 100 biji. (11). Jumlah bunga pita setiap tanaman (helai), (12) $\mathrm{LD}_{50}$, (13) Kandungan klorofil, (14). Pengamatan karakter kualitatif seperti warna bunga (dibandingkan menggunakan standart warna Munsell Colour Chart). (15). Heritabilitas. (16). 
Perubahan keragaan fenotip.

\section{Rancangan Percobaan dan Analisis Data}

Rancangan yang digunakan pada penelitian ini adalah percobaan monofaktor dengan rancangan acak lengkap (RAL) terdiri dari 5 perlakuan iradiasi sinar gamma dan 5 ulangan, setiap ulangan terdiri 5 benih bunga matahari. Perlakuan iradiasi sinar gamma yang dicobakan adalah dosis $0,5,25,45$, dan 65 Gy. Data pengamatan yang diperoleh akan dianalisis dengan menggunakan analisa ragam (uji F) pada taraf 5\%. Bila hasil pengujian diperoleh pengaruh yang nyata maka dilanjutkan dengan uji lanjut BNT.

\section{HASIL DAN PEMBAHASAN}

\section{Keragaan Karakter Kuantitatif Helianthus annuus $\mathrm{L}$.}

Hasil pengamatan biji bunga matahari setelah diiradiasi sinar gamma diperlihatkan pada Tabel 1 . Iradiasi sinar gamma biji bunga matahari berpengaruh terhadap karakter morfologi bunga matahari yaitu tinggi tanaman, diameter batang, umur inisiasi buga, diameter bunga pita dan tabung, total berat biji, total jumlah biji dan bobot 100 biji. Iradiasi sinar gamma mampu merubah karakter morfologi tanaman. Hal ini sesuai dengan pendapat Mayasari (2007) bahwa keragaman karakter tinggi tanaman dapat ditingkatkan melalui iradiasi sinar gamma. Menurut Batubara (2015) dosis iradiasi yang tinggi mengakibatkan penurunan panjang tanaman bawang merah. Hal ini terbukti dengan adanya perbedaan tinggi tanaman di setiap perlakuan dosis iradiasi pada Ilustrasi 1.

Diameter batang, bunga pita, bunga tabung dan umur inisiasi pada bunga matahari mengalami penurunan ukuran dan mempercepat umur inisiasi bunga (Tabel 2) dikarenakan semakin besarnya dosis penyinaran mengakibatkan terjadinya kerusakan proses fisiologi pada tanaman. Kerusakan fisiologi tanaman mengakibatkan perubahan dalam susunan jaringan tanaman dan metabolisme tanaman dalam fotosintesis. Hal ini sesuai dengan pendapat Metwally et al. (2015)

Tabel 1. Rekapitulasi Sidik Ragam Pengaruh Dosis Sinar Gamma terhadap Karakter Kuantitatif Bunga Matahari

\begin{tabular}{|c|c|c|c|c|c|}
\hline Peubah & Waktu & $\begin{array}{l}\text { Uji F } \\
\text { Dosis }\end{array}$ & $\mathrm{CV} \%$ & $\begin{array}{c}\text { Heritabilitas } \\
(\%)\end{array}$ & Kriteria \\
\hline Umur perkecambahan & $1-4 \mathrm{MST}$ & tn & 1,6 & & \\
\hline Tinggi tanaman & 42-65 UMS & * & 22,56 & 73,2 & Tinggi \\
\hline Diameter batang & 42-65 UMS & * & 2,19 & 23,47 & Rendah \\
\hline Umur inisiasi bunga & 15-34 HST & * & 13,81 & 88,1 & Tinggi \\
\hline Umur mekar sempurna & 42-65 HST & th & 18,89 & & \\
\hline Diameter bunga pita & 42-65 HST & $*$ & 12,04 & 66,6 & Tinggi \\
\hline Diameter bunga tabung & 42-65 HST & $*$ & 7,66 & 66,03 & Tinggi \\
\hline Jumlah bunga pita & 42-65 HST & th & 16,5 & & \\
\hline Total berat biji & $12 \mathrm{MST}$ & $*$ & 13,23 & 70,5 & Tinggi \\
\hline Total jumlah biji & $12 \mathrm{MST}$ & $*$ & 29,84 & 69,1 & Tinggi \\
\hline Bobot 100 biji & $12 \mathrm{MST}$ & $*$ & & 73,81 & Tinggi \\
\hline Klorofil A ( $\mu$ mol $)$ & 42-65 UMS & th & 1,57 & & \\
\hline Klorofil B ( $\mu \mathrm{mol})$ & 42-65 UMS & th & 1,22 & & \\
\hline Klorofil total $(\mathrm{A}+\mathrm{B})(\mu \mathrm{mol})$ & 42-65 UMS & $\operatorname{tn}$ & 2,04 & & \\
\hline $\begin{array}{l}\text { Keterangan: } \\
\text { tn : Tidak Nyata } \\
*: \text { Signifikan taraf } 5 \%\end{array}$ & & $\begin{array}{l}\text { HST }: \text { H } \\
\text { MST }: 1\end{array}$ & $\begin{array}{l}\text { i Setelal } \\
\text { nggu Se }\end{array}$ & $\begin{array}{l}\text { ransplanting } \\
\text { h Tanam }\end{array}$ & \\
\hline
\end{tabular}




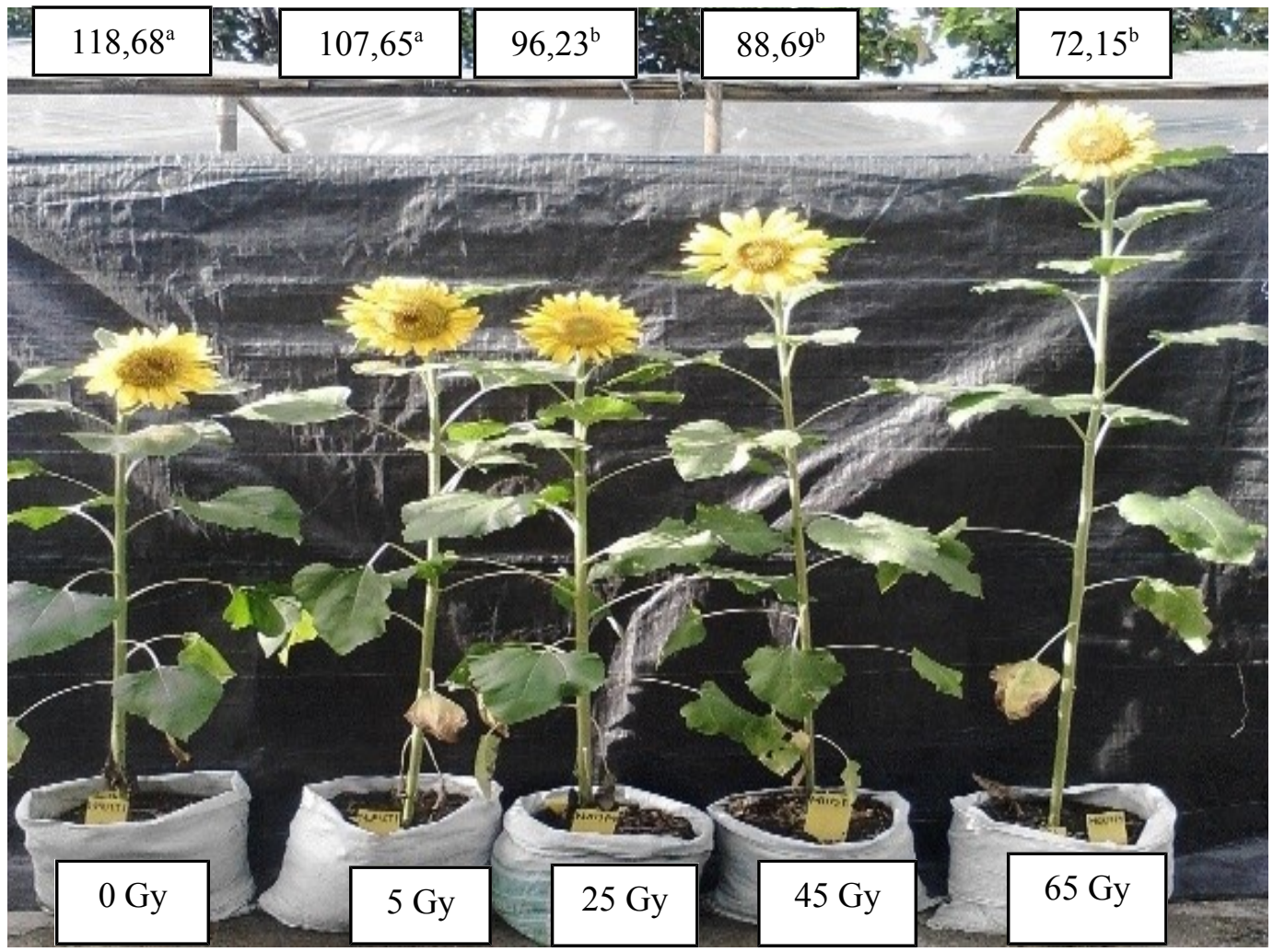

Ilustrasi 1. Perbandingan tinggi tanaman bunga matahari umur mekar sempurna

bahwa iradiasi memberikan efek perubahan struktur seluler tanaman, metabolisme dan fotosintesis.

Hasil penelitian Khotimah (2007) tentang budidaya bunga matahari menghasilkan umur inisiasi bunga matahari sekitar 19-22 hst. Iradiasi memberikan kontribusi dalam hal mempercepat umur inisiasi bunga matahari, yang berarti mampu mengurangi lamanya waktu pemanenan. Inisiasi adalah munculnya awalan pembungaan suatu tanaman. Menurut Saputra (2012) iradiasi mampu mempercepat fase generatif suatu tanaman.

Tabel 2. Diameter Batang, Diameter Bunga Pita, Diameter Bunga Tabung dan umur inisiasi Bunga Matahari Waktu Mekar Sempurna pada Perlakuan Iradiasi Gamma.

\begin{tabular}{|c|c|c|c|c|c|}
\hline \multirow{2}{*}{$\begin{array}{c}\text { Peubah } \\
(\mathrm{cm})\end{array}$} & \multicolumn{5}{|c|}{ Dosis } \\
\hline & 0 & 5 & 25 & 45 & 65 \\
\hline Diameter batang & $2.12^{\mathrm{a}}$ & $197^{\mathrm{b}}$ & $1.88^{\mathrm{c}}$ & $186^{c}$ & $1.72^{\mathrm{c}}$ \\
\hline Diameter bunga pita & $15,25^{\mathrm{a}}$ & $12,26^{\mathrm{b}}$ & $\begin{array}{r}1,00 \\
11,03^{\mathrm{c}}\end{array}$ & $10,60^{\mathrm{d}}$ & $9,28^{\mathrm{e}}$ \\
\hline Diameter bunga tabung & $6,73^{\mathrm{a}}$ & $5,56^{\mathrm{b}}$ & $4,74^{\mathrm{c}}$ & $4,78^{\mathrm{c}}$ & $4,08^{\mathrm{d}}$ \\
\hline Jumlah bunga pita & 28,60 & 24,4 & 22,4 & 23,68 & 18,00 \\
\hline Umur inisiasi bunga & $22,80^{\mathrm{a}}$ & $17,36^{\mathrm{b}}$ & $16,88^{\mathrm{b}}$ & $16,56^{\mathrm{b}}$ & $15,24^{\mathrm{c}}$ \\
\hline
\end{tabular}

Keterangan: Nilai yang diikuti oleh huruf yang sama pada baris yang sama tidak berbeda nyata pada uji lanjut BNT. 
Percepatan fase generatif bisa disebabkan oleh berubahnya susunan genetik yang mengakibatkan perbedaan genetik oleh individu lain meskipun dari jenis yang sama.

Hasil analisis ragam menunjukkan bahwa iradiasi sinar gamma berpengaruh nyata terhadap total berat biji, total jumlah biji, dan bobot 100 biji. Total berat biji, total jumlah biji, dan bobot 100 biji tersaji pada Tabel 3.

Ketiga peubah yang digunakan pada Tabel 3 menunjukkan bahwa semakin tinggi dosis penyinaran iradiasi sinar gamma yang digunakan dapat menurunkan hasil produksi biji. Peningkatan dosis iradiasi mampu menurunkan produksi bawang merah (Batubara, 2015) dan produksi jumlah biji tanaman kembang telang (Sajimin et al., 2015). Tabel 3 menunjukkan bahwa pada dosis 5 Gy memiliki total jumlah biji sebanyak 322 butir dengan total berat biji $8,39 \mathrm{~g}$ sementara dosis 45 Gy memiliki total jumlah biji 330,28 butir akan tetapi total berat biji hanya 7,09 g. Mutasi bersifat acak, diduga karena efek mutasi mengakibatkan bahwa iradiasi menyebabkan perubahan genetik yang mengakibatkan susunan gen yang berbeda. Tingkat radiosensitivitas yang rendah juga bisa menyebabkan mutasi tidak dapat menembus kedalam sel. Menurut Maharani (2015) mutasi bisa terjadi apabila iradiasi mampu menembus dinding sel. Hal ini mungkin disebabkan karena sel-sel normal mampu terus berkembang dan bersaing dengan sel yang termutasi. Menurut pendapat Devy dan Sastra (2016) bahwa kelompok sel-sel normal mampu bersaing dengan sel termutasi sehingga terjadinya sel mutasi yang terseleksi.

\section{Persentase Tanaman Hidup dan Lethal Dose 50 (LD50)}

Dari data yang disajikan pada Tabel 4 dapat dilihat bahwa peningkatan dosis sinar gamma menyebabkan penurunan persentase tanaman hidup bunga matahari.

Nilai LD50 diperoleh melalui persentase

Tabel 3. Total Berat Biji, Total Jumlah Biji, dan Bobot 100 biji Bunga Matahari pada Perlakuan Iradiasi Sinar Gamma.

\begin{tabular}{|c|c|c|c|c|c|}
\hline \multirow{2}{*}{ Peubah } & \multicolumn{5}{|c|}{ Dosis } \\
\hline & 0 & 5 & 25 & 45 & 65 \\
\hline Total berat biji (g) & $9,40^{\mathrm{a}}$ & $8,39^{\mathrm{b}}$ & $\begin{array}{l}-(\mathrm{Gy}) \\
5,45^{\mathrm{c}}\end{array}$ & $7,09^{d}$ & $4,30^{\mathrm{e}}$ \\
\hline Total jumlah biji (butir) & $345,16^{\mathrm{a}}$ & $322,00^{\mathrm{b}}$ & $223,84^{b}$ & $330,28^{\mathrm{b}}$ & $178,20^{\mathrm{c}}$ \\
\hline Bobot 100 biji (butir) & $51,14^{\mathrm{a}}$ & $61,14^{\mathrm{a}}$ & $61,75^{\mathrm{a}}$ & $59,75^{\mathrm{a}}$ & $69,64^{\mathrm{a}}$ \\
\hline
\end{tabular}

Keterangan: Nilai yang diikuti oleh huruf yang sama pada kolom yang sama tidak berbeda nyata pada uji lanjut BNT.

kekosongan biji meskipun jumlah biji berpengaruh terhadap berat biji. Hal ini sesuai dengan pendapat Warman et al. (2015) bahwa iradiasi mampu menyebabkan kekosongan biji pada tanaman padi. Perbedaan berat biji tergantung dari besar kecilnya diameter bunga tabung pada tiap dosis. Semakin kecil ukuran diameter tabung, maka berpengarauh terhadap total jumlah biji bunga matahari.

Tidak adanya pengaruh dosis penyinaran terhadap karakter morfologi lain diduga karena tingkat radiosensitivitas yang rendah sehingga tidak adanya perubahan materi genetik yang menyebabkan mutasi. Menurut Daeli et al. (2013) tanaman hidup setelah diiradiasi melaui progam curve fit analysis. Persentase tanaman hidup diperoleh pada waktu tanaman sudah berbunga mekar sempurna atau 65 hst (hari setelah transplanting) karena perbedaan daya berkecambah setiap benih. Persentase tanaman hidup pada tabel 4 menunjukkan hingga pada dosis tertinggi (65 Gy) tanaman bunga matahari masih tumbuh dan bertahan hidup lebih sedikit dibanding dosis rendah tetapi persentase hidup masih diatas $50 \%$. Artinya bahwa $\mathrm{LD}_{50}$ iradiasi sinar gamma untuk biji bunga matahari lebih besar dari 65 Gy. Menurut Ramadhani (2015) bahwa daya berkecambah benih akan semakin menurun 
seiring meningkatnya dosis penyinaran. Penurunan daya berkecambah benih dapat juga diakibatkan karena matinya sel yang terkena paparan radiasi. Hal ini sesuai dengan pendapat Mubarok et al. (2011) bahwa penurunan presentase perkecambahan akibat efek deterministik yaitu kematian sel akibat paparan radiasi. Tabel 4 menampilkan persamaan matematika yang diperoleh melalui analisis Curve-fit untuk memperoleh nilai $\mathrm{LD}_{50}$. Nilai $\mathrm{LD}_{50}$ biji bunga matahari akibat iradiasi sinar gamma adalah 74,19 Gy. Nilai tersebut melebihi dari batas dosis pada penelitian, dengan arti lain jika akan ada penelitian mutasi fisik tentang bunga matahari dapat menggunakan kisaran dosis 74 Gy. Nilai tersebut sesuai dengan hasil penelitian karena pada dosis 65 Gy biji yang tidak berkecambah tidak mencapai $50 \%$. berbeda dari dosis kontrol. Penelitian Karyanti et al. (2015) radiasi merubah warna kalus jeruk keprok garut akibat rusaknya fase fisiologi. Efek penyinaran memberikan dampak perubahan warna bunga pita yang berbeda seperti induknya. Menurut Suliansyah (2011) hasil mutasi yang memiliki warna bunga yang berbeda dengan warna aslinya disebut mutan klorofil. Iradiasi sinar gamma pada bunga matahari tidak menunjukkan perubahan warna bunga pita yang secara beda nyata terhadap tanaman kontrol. Warna bunga pita hanya mengalami sedikit perubahan pada komposisi pigmen sehingga menciptakan warna kuning yang lebih gelap ataupun lebih terang dari warna tanaman kontrol. Perubahan warna bunga pita yang tidak terlalu berbeda nyata dengan tanaman kontrol diduga karena dosis penyinaran belum mencapai nilai

Tabel 4. Persentase tanaman hidup pada 65 hst (hari setelah transplanting) dan Nilai $\mathrm{LD}_{50}$

\begin{tabular}{ccccc}
\hline $\begin{array}{c}\text { Dosis } \\
\text { (Gy) }\end{array}$ & $\begin{array}{c}\text { \% Tanaman } \\
\text { Hidup }\end{array}$ & Model & Persamaan Linier & $\begin{array}{c}\text { Nilai LD } \text { LD }_{50} \\
(\mathrm{~Gy})\end{array}$ \\
\hline 0 & 100 & & & \\
5 & 80 & & & \\
25 & 80 & Linear Fit: $\mathrm{y}=\mathrm{a}+\mathrm{bx}$ & $\mathrm{y}=-0,336 \mathrm{x}+91,034$ & 74,19 \\
45 & 80 & & & \\
65 & 68 & & & \\
\hline
\end{tabular}

\section{Keragaan Karakter Kualitaif Helianthus annuus $\mathrm{L}$.}

Perlakuan iradiasi sinar gamma pada penelitian ini membentuk 4 mutan berdasarkan warna bunga pita. Pengamatan warna bunga pita dilakukan pada waktu umur mekar sempurna yaitu umur 42-65 hst (hari setelah transplanting) menggunakan perbandingan warna munsell colour charts. Perubahan warna bunga pita bunga matahari diduga karena kerusakan fase fisiologi tanaman sehingga menghasilkan jenis warna yang
$\mathrm{LD}_{50}$ sehingga perubahan fenotipik belum terlihat jelas. Ramadhani (2015) warna daun Heliconia spp tidak menunjukkan perbedaan yang jauh dengan tanaman induknya karena penyinaran belum mencapai nilai $\mathrm{LD}_{50}$.

Ilustrasi 2 menunjukkan warna asli dari bunga matahari varietas giant single yaiu warna kuning jeruk dengan kode warna 2,5y 8/8 yang diikuti dengan dosis lain yaitu 5, 25, 45 dan 65 Gy.

Ilustrasi 3 merupakan warna bunga matahari hasil iradiasi sinar gamma dengan warna kuning jeruk pucat berkode warnna 2,5 y $8 / 6$ yang 

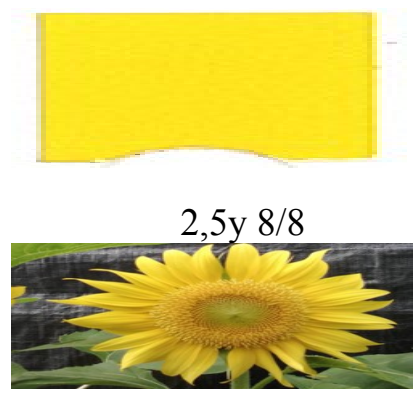

25 Gy

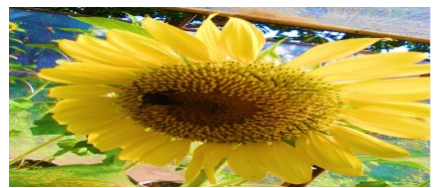

0 Gy (Kontrol)

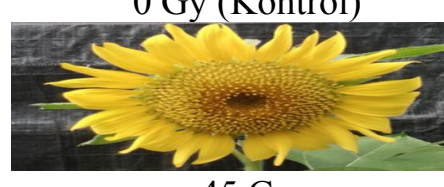

45 Gy

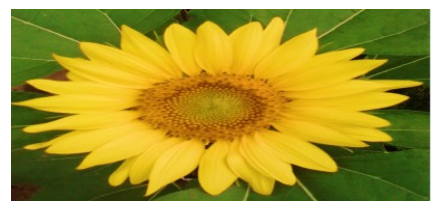

5 Gy

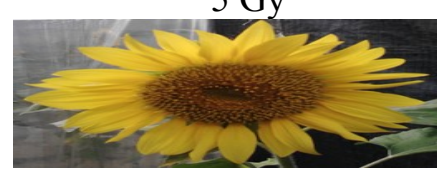

65 Gy

Ilustrasi 2. Keragaman warna bunga 2,5 y $8 / 8$

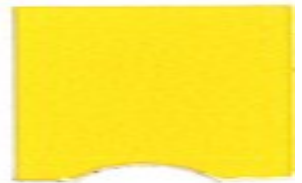

2,5 y $8 / 6$

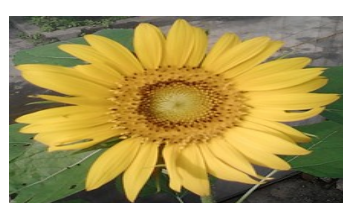

5 Gy

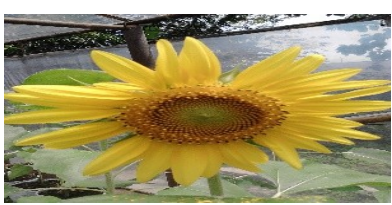

25 Gy

Ilustrasi 3. Keragaman warna bunga 2,5y 8/6

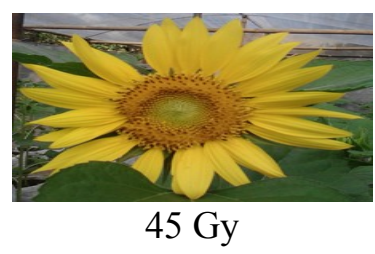

45 Gy

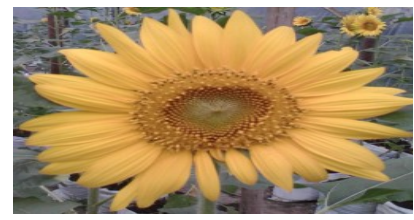

65 Gy

5 Gy

Ilustrasi 4. Keragaman 2,5y 7/8.

45 Gy

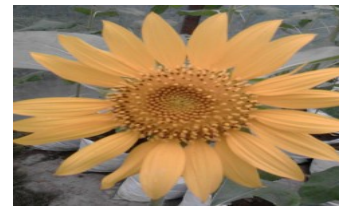

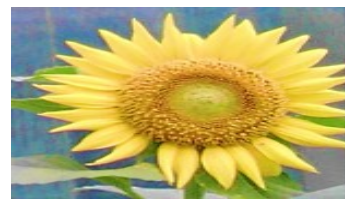

2,5 y $7 / 8$

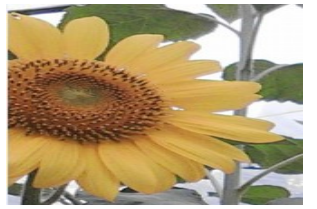

5 Gy

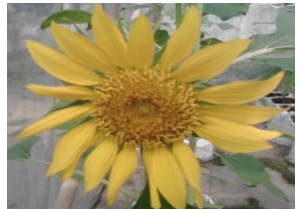

$25 \mathrm{~Gy}$

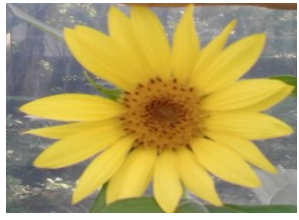

45 Gy

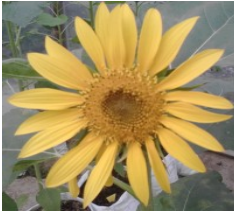

$65 \mathrm{~Gy}$

Ilustrasi 5. Keragaman warna 5y 8/8.

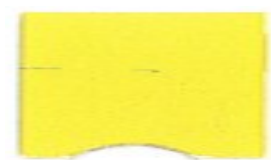

5 y $8 / 6$

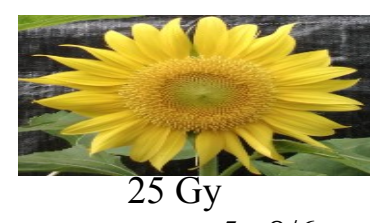

$25 \mathrm{~Gy}$

Ilustrasi 6. Keragaman warna 5 y $8 / 6$ 
terdapat pada dosis 5 Gy, 25 Gy dan 45 Gy.

Ilustrasi 4 merupakan warna bunga matahari hasil iradiasi sinar gamma dengan warna kuning kunyit berkode warnna 2,5 y $7 / 8$ yang terdapat pada dosis 5 Gy, 45 Gy dan 65 Gy.

Ilustrasi 5 merupakan warna bunga matahari hasil iradiasi sinar gamma dengan warna kuning lemon berkode warnna 5 y $8 / 8$ yang terdapat pada dosis 5 Gy, 25 Gy, 45 Gy dan 65 Gy.

Ilustrasi 6 merupakan warna bunga matahari hasil iradiasi sinar gamma dengan warna kuning lemon pucar berkode warnna 5 y $8 / 6$ yang terdapat pada dosis $5 \mathrm{~Gy}$.

\section{Perubahan Keragaan Fenotip}

Iradiasi menyebabkan terjadinya perubahan fenotip yang ditandai dengan adanya perubahan fisik pada tanaman. Perubahan fenotip bisa mengarah pada perubahan fenotip positif seperti bentuk bunga, daun maupun warna bunga. Menurut Aisyah (2006) bahwa pada bunga anyelir perubahan mutan positif terlihat pada warna bunga bunga. Ilustrasi 7 merupakan tampilan tanaman bunga matahari yang mengalami efek iradiasi sinar gamma yaitu pada daun terlihat variegata.

Ilustrasi 8 merupakan bentuk bunga matahari yang mengalami efek iradiasi sinar gamma terlihat dari bentuk bunga tabung yang tidak bulat penuh.

Perubahan fenotip pada Ilustrasi 7 dan 8 diduga karena akibat iradiasi sinar gamma. Mutasi pada tanaman bersifat acak (Maharani, 2015), terbukti dari 100 tanaman yang diberi perlakuan hanya 3 tanaman yang mengalami perubahan fenotipik khusus. Menurut Daeli et al. (2013) bahwa peralihan materi gen menyebabkan tanaman memiliki ciri khusus. Perubahan materi gen mampu mengganggu sintesis khlorofil dalam proses fotosintesis sehingga tanaman akan mengalami defisiensi warna hijau sehingga
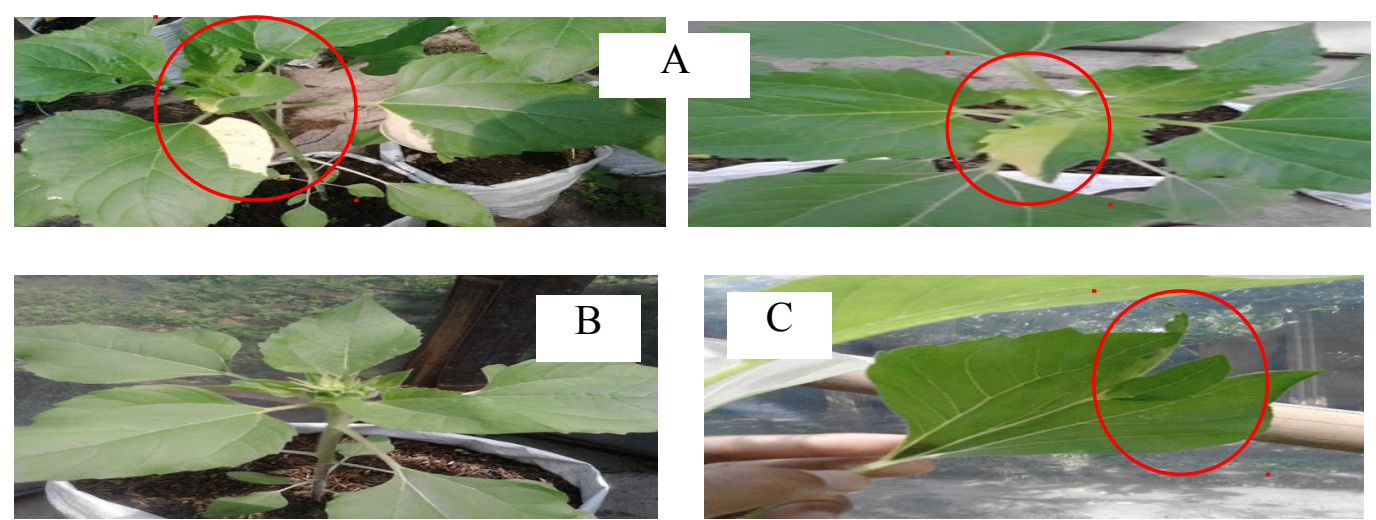

Ilustrasi 7. Perubahan Warna dan bentuk daun akibat iradiasi sinar gamma saat inisiasi bunga 15-34 hst. (A) dosis 45 Gy (Varigata), (B) daun normal. (C) dosis 65 Gy
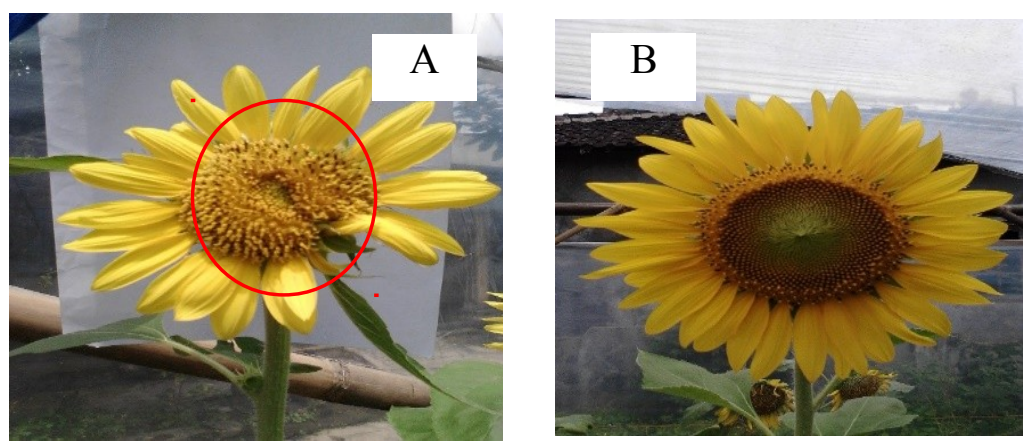

Ilustrasi 8. Perubahan kerapatan bunga pita akibat iradiasi sinar gamma saat umur mekar sempurna. (a) dosis 65 Gy. (b) dosis 0 Gy (kontrol). 


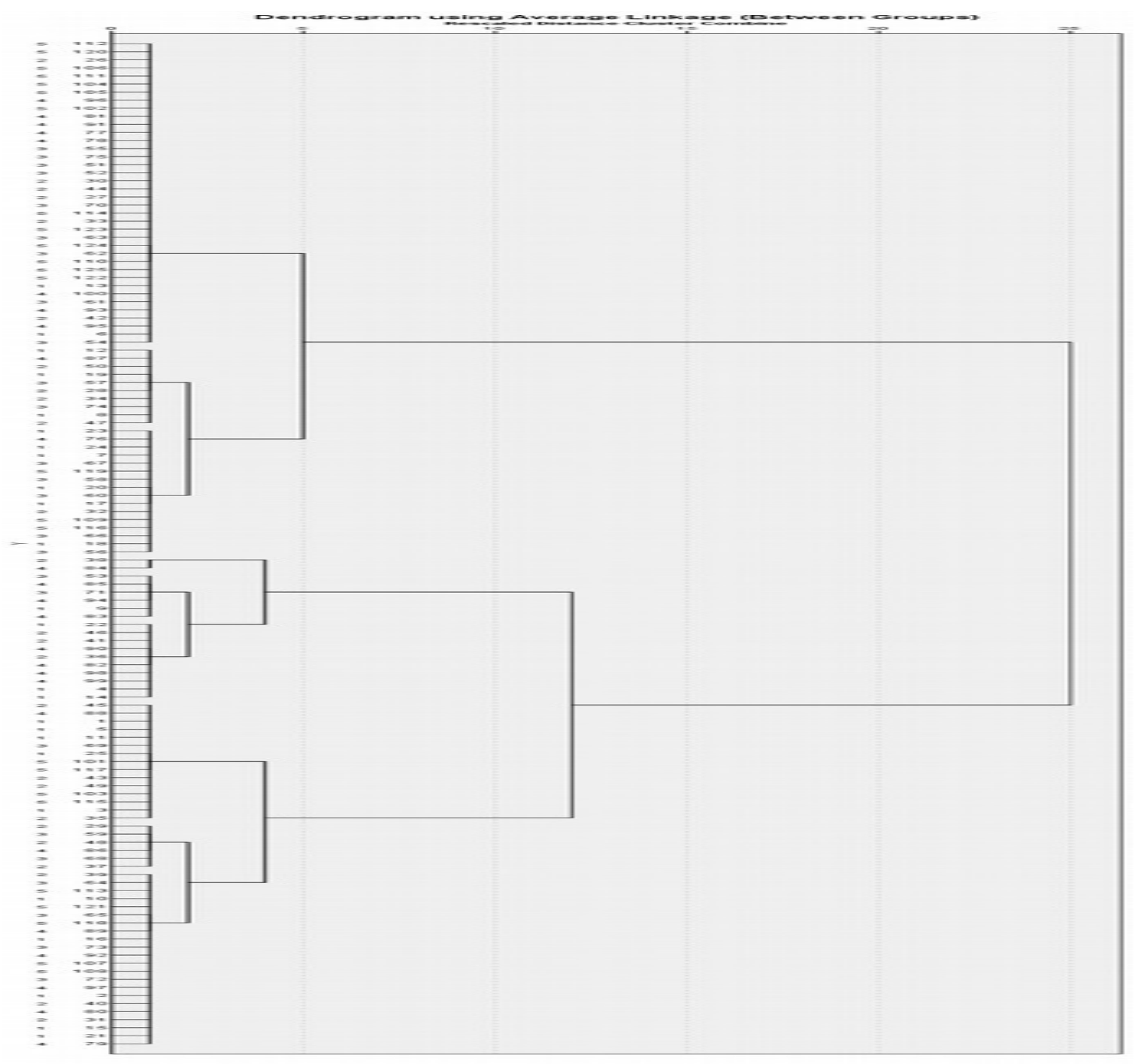

Ilustrasi 9. Dendogram hasil analisis 125 mutan bunga matahari

muncul daun variegata putih (albino) dan kuning (viridis). Aisyah (2006) pada tanaman anyelir terjadi daun variegata akibat iradiasi sinar gamma yang mengganggu proses sintesa khlorofil. Hal ini diperkuat dengan pendapat Suliansyah (2011) bahwa tanaman hasil mutasi memiliki warna daun yang berbeda dengan indukannya. Daun yang variegata hanya bertahan hingga bunga mekar sempurna (65 hst) dan mengalami kematian pada bagian daun variegata bukan keseluruhan tanaman. Bunga yang muncul dari tanaman berdaun variegata juga berpenampilan normal seperti kontrol. Hasil mutasi tidak selamanya mengarah pada mutasi positif yang memberikan keragaman unik. Ilustrasi 8 menunjukkan hasil mutasi yang menurut penulis adalah hasil mutasi bersifat negatif karena bentuk bunga tabung yang tidak bulat penuh dan kerapatan bunga pita yang jarang. Dosis penyinaran yang tinggi mampu mengganggu proses fisiologi tanaman yang menyebabkan rusaknya sel meristem. Sesuai dengan pendapat Cahyono dan Dinarti (2015) bahwa dosis yang tinggi mampu merusak sel meristem tanaman anggrek. 


\section{Keragaman Helianthus annuus L.}

Hasil dendogram Ilustrasi 9 menunjukkan bahwa tanaman bunga matahari terbagi menjadi 2 kelompok utama yaitu kelompok A terdiri dari 64 tanaman yaitu tanaman nomor 112, 120, 26, 106, $111,104,105,96,102,81,91,77,78,55,75,51$, $52,30,44,27,70,114,33,123,63,124,62,110$, $125,122,13,100,61,93,42,95,6,54,12,87,50$, $19,57,28,34,74,8,47,23,76,24,7,67,119,58$, $20,60,17,32,109,116,66,18$, dan 56 . Kelompok B terdiri dari dari 61 tanaman yaitu tanaman nomor $38,84,53,85,71,94,9,83,22$, $46,41,90,36,82,98,99,4,14,45,88,1,5,11$, $69,25,101,117,43,49,103,115,3,35,29,59$, $48,86,68,37,39,64,113,10,121,65,118,89$, $16,73,92,107,108,72,97,2,40,8031,15,21$, dan 79 .

Analisis hubungan kekerabatan terhadap 8 karakter morfologi bunga matahari menghasilkan dendogram dengan koefisien kemiripan berkisar $0-25 \%$. Karakter tersebut antara lain tinggi tanaman, diamater batang, diameter bunga pita, diamater bunga tabung, umur inisiasi bunga, jumlah biji, total berat biji, dan persentase 100 biji. Dendogram pada ilustrasi 9 memperlihatkan bahwa tanaman bunga matahari hasil mutasi dapat dikelompokkan menjadi 2 kelompok besar pada koefisien kemiripan $25 \%$ dengan kelompok A terdiri dari 61 tanaman akan tetapi 22 tanaman lainnya mati sedangkan kelompok b terdiri dari 64 tanaman. Kelompok A terbagi menjadi 2 sub kelompok kecil yaitu kelompok $\mathrm{C}$ dan $\mathrm{D}$ dengan nilai koefisien kemiripan 5\% sedangkan kelompok B terbagi menjadi 2 sub kelompok kecil yaitu kelompok $\mathrm{E}$ dan $\mathrm{F}$ dengan nilai koefisien kemiripan 12\%. Kelompok E memiliki karakter yang sama yaitu karakter tinggi tanaman dimana tinggi tanaman melebihi $100 \mathrm{~cm}$ sedangkan untuk warna bunga pita banyak yang berbeda dengan warna bunga pita tanaman kontrol. Hasil analisis kekerabatan ditampilkan dalam bentuk dendogram dan dilihat koefisien kemiripan dari sampel tanaman bunga matahari. Menurut pendapat Wulansari (2014) koefisien kemiripan digunakan sebagai acuan penilaian ukuran derajat kedekatan genetik antar tanaman. Semakin besar nilai koefisien kemiripan bunga matahari semakin besar keragaman bunga matahari akibat penyinaran iradiasi sinar gamma. Menurut Herawati et al. (2012) bahwa keragaman ditandai dengan banyakya persamaan sebaliknya jika semakin banyaknya perbedaan maka semakin jauh hubungan kekeratan.

\section{KESIMPULAN}

Hasil penelitian menunjukkan perlakuan penyinaran iradiasi sinar gamma mengubah keragaman morfologi bunga matahari pada karakter tinggi tanaman, diameter batang, umur inisiasi bunga, diameter bunga pita, diamater bunga tabung, warna bunga, total jumlah biji, total berat biji dan persentase 100 biji. Nilai $\mathrm{LD}_{50}$ pada penyinaran iradaisi sinar gamma untuk tanaman bunga matahari adalah 74,19 Gy.

\section{DAFTAR PUSTAKA}

Aisyah, S. I. 2006. Induksi agen fisik pada anyelir (Diathus caryophyllus Linn.) dan pengujian stabilitas mutannya yang diperbanyak secara vegetatif. Disertasi. Institut Pertanian Bogor, Bogor.

Balai Penelitian Pertanian. 2011. Pemanfaatan sinar radiasi dalam pemuliaan tanaman. Balai Besar Penelitian dan Pengembangan Bioteknologi dan Sumberdaya Geetik Pertanian. 33 (1) :7-8.

Batubara, A. U., Mariati., dan F. E. T. Sitepu. 2015. Karakter pertumbuhan bawang merah (Allium ascalonicum L.) varietas lokal samosir pada beberapa dosis iradiasi sinar gamma. J. Online Agroekoteknologi. 3 (1) : $426-434$.

Cahyo, F. A. dan Dinarti, D. 2015. Pengaruh iradiasi sinar gamma terhadap pertumbuhan protocorm like bodies anggrek Dendrobium lasianthera (JJ. Smith) secara in vitro. 6 (3) : 177-186.

Daeli, N. D. S., L. A. Putri., I. Nuriadi. 2013. Pengaruh radiasi sinar gamma terhadap kacang hijau (Vigna radiata L.) pada kondisi salin. J. Online Agroekoteknologi. 1 (2) : 227-237. 
Devy, L. dan Sastra, D. R. 2006. Pengaruh iradiasi sinar gamma terhadap kultur in vitro tanaman jahe. J. Sains dan Teknologi Indonesia. 8 (1) : 1-14.

Herawati, W., Chasanah, T., dan Kamsinah. 2012. Karakteristik salak lokal banyumas (Salacca zalacca (Gaert) Voss) sebagai upaya pelestarian spesies indi genous. Prosiding Seminar Nasional, Purwokerto.

Karyanti, Purwito, A., dan Husni, A. 2015. Radiosensitivitas dan seleksi mutan putatif jeruk keprok garut (Citrus reticulata L.) berdasarkan penanda morfologi. J. Agron. Indonesia. 43 (2) : 126-132.

Khotimah. 2007. Karakterisasi pertumbuhan dan perkembangan berbagai varietas bunga matahari (Helianthus annuus L.). Skripsi. Institut Pertanian Bogor, Bogor.

Maharani, S. dan Khumaida, N. 2013. Induksi keragaman dan karakterisasi dua varietas krisan (Dendranthema grandiflora Tzvelev) dengan iradiasi sinar gamma secara in vitro. J. Hortikultura Indonesia. 4 (1): 34-43.

Maharani, S., N. Khumaida, M. Syukur, dan S. W. Ardie. 2015. Radiosensitivitas dan keragaman ubi kayu (Manihot esculenta Crantz) hasil iradiasi sinar gamma. J. Agron. Indonesia 43 (2) : 111-117.

Mayasari, I. G. A. D. P. 2007. Pengaruh iradiasi sinar gamma terhadap keragaman legkuas merah (Alpinia purpurata K. Schum). Skripsi. Institut Pertanian Bogor, Bogor.

Metwally, S. A., A. R. E. Awad., B. H. A. Leila., T. A. A. E. Tayeb., dan I. E. A. Habba. 2015. Studies on the effect of gamma, laser irradiation and progesterone treatments on gerbera leaves. J. of Biophysiscs, EGypt.

Nura., M. Syukur., N. Khumaida., dan Widodo. 2015. Radiosensitivitas dan heretabilitas ketahanan terhadap penyakit antraknosa pada tiga populasi cabai yang diinduksi irradiasi sinar gamma. J. Agron. Indonesia. 43 (3) : $201-206$.

Ramadhani, N. A. 2015. Penentuan lethal dose 50 $\left(\operatorname{ld}_{50}\right)$ iradiasi sinar gamma pada beberapa kultivar Heliconia spp. Skripsi. Institut Pertanian Bogor, Bogor.

Sajimin, Fanindi, A., dan Purwantari, N. D. 2015. Pengaruh radiasi sinar gamma terhadap produksi dan kualitas benih tanaman pakan ternak kembang telang (Clitoria ternatea M2) di bogor. Prosiding Seminar Nasional Teknologi Peternakan dan Veteriner.

Saputra, M H. C. 2012. Pengaruh mutasi fisik melalui iradiasi sinar gamma terhadap keragaan bunga matahari (Helianthus annuus L.). Skripsi. Institut Pertanian Bogor, Bogor.

Suliansyah, I. 2011. Perbaikan padi lokal sumatera barat melalui pemuliaan mutasi. Seminar Nasional: Reformasi Pertanian Terintegrasi Menuju Kedaulatan Pangan. Madura.

Suwarno, A., N. A. Habibah.,dan L. Herlina. 2013. Respon pertumbuhan planlet anggrek Phalaeonopsis amabilis L. var. jawa candiochid akibat radiasi Sinar gamma. Unnes Journal of Life Science. 2 (2): 78-84.

Syukur, M. Sujiprihati, S. dan Yunianti, R. 2012. Teknik Pemuliaan Tanaman. Penebar Swadaya, Depok.

Warman, B., Sobrizal, I. suliansyah, E. Swasti, dan A. Syarif. 2015. Perbaikan genetik kultivar padi beras hitam lokal sumatera barat melalui mutasi induksi. J. Ilmiah Aplikasi Isotop dan Radiasi. 11 (2) : 125 135.

Wulansari, R. 2014. Studi kekerabatan dan morfologi padi lokal adan hasil mutasi sinar gamma. Skripsi. Institut Pertanian Bogor, Bogor. 